\title{
NUTRITIONAL SURVEILLANCE FOR STUNTING AMONG CHILDREN UNDER FIVE YEARS OLD IN JEMBER DISTRICT
}

\author{
Sri Wahyuni Adriani1), Rini Kusuma Wardani²) \\ 1)Lecturer of Faculty of Health Science University of Muhammadiyah Jember \\ 2)Student of Faculty of Health Science University of Muhammadiyah Jember \\ Corresponding e-mail: sriwahyuni@unmuhjember.ac.id
}

\begin{abstract}
BACKGROUND : Stunting is a nutritional problem in children, where the child has a significantly shorter body compared to the average age of the child. Stunting affects an individual's educational and wage-earning potential and can even affect the next generation of children. The aim of the study was undertaken to assess the risk factors associated with stunting among children under five years old in jember district.

SUBJECT AND METHODE: this study was descriptive survey in the working area of Sukowono Public Health Center. A total of 249 children were selected for nutritional assessment in terms of stunting using the new World Health Organization growth standards.

RESULTS : Hierarchical logistic regression was used to examine the risk factors for adverse nutritional status. Hierarchical logistic regression analysis showed that the risk factors for stunted children were duration of exclusive breastfeeding ( $<6$ months), low birthweight, and pregnancy anaemia. These results indicate that malnutrition especially stunting is still a major public health problem among children under five years old.
\end{abstract}

CONCLUSION: The government should implement appropriate nutritional intervention strategies to help reduce the prevalence and risk factors of stunting in children.

Keywords: Stunting, Risk Factors, Children Under Five Years

\section{INTRODUCTION}

Stunting is a nutritional problem in children, where the child has a significantly shorter body compared to the average age of the child in his time. Stunting is still a major nutritional problem in both developed and developing countries. WHO estimates that the prevalence of stunting in Latin America in 2015 was $11.3 \%$, affecting 6.1 million children under five years (WHO, 2014).

The prevalence of short toddlers in Indonesia continues to increase from year to year (in 2007 by $18 \%$, in 2013 as many as $19.2 \%$, and in 2018 a number of $19.3 \%$ of short toddlers), with the total number of toddlers very short and short of $30,8 \%$ (Riskesdas, 2018). Indonesia is included in 17 countries among 117 countries that have three nutritional problems, namely stunting, wasting, and overweight (Achadi, 2015). East Java is one of the provinces with a high prevalence of stunting under five $(30 \%-<40 \%)$ at $32 \%$ (Riskesdas, 2018). Whereas in Jember the number of stunted children was 80,359 or around $44.1 \%$ (TNP2K, et.al, 2013). 
Nutritional problems, especially stunting (short children), can hamper children's development, with negative impacts that will take place in the next life. Studies show that short children are strongly associated with poor educational performance, decreased length of education and low income as adults. Short children face a greater likelihood of growing into adults who are less educated, poor, less healthy and more vulnerable to non-communicable diseases. Therefore, short children are a predictor of the poor quality of widely accepted human resources, which in turn reduces the productive ability of a nation in the future (UNICEF, 2012). This condition is a major public health problem (Prendergast \& Humphrey 2014).

Although Indonesia has shown a steady reduction in poverty, nutrition problems in children still show a slight improvement. From 2007 to 2011, the proportion of poor people in Indonesia decreased by $16.6-12.5 \%$, but nutrition problems did not show a significant decrease. The prevalence of short children is very high, affecting one in three children under five, which is a proportion that is a public health problem according to WHO criteria (UNICEF, 2012).

The proportion of short children in the poorest population quintile is almost double the proportion of children in the highest wealth quintile. Rural areas have a greater proportion of short children $(40 \%)$ compared to urban areas (33\%). The prevalence of short children living in households with uneducated household heads is 1.7 times higher than the prevalence among children living in households with highly educated household heads (Kemenkes RI, 2018).

Under these conditions it is necessary to have a strategy to tackle stunting, one of which is through nutritional surveillance. Nutrition surveillance is the act of observing the state of nutrition continuously and regularly for decision making for efforts to improve and prevent the deterioration of the nutritional state of the community. Surveillance actions include conducting Nutrition Status Monitoring (PSG), situation analysis, and growth monitoring. The results of surveillance can be a strong and appropriate basic data in formulating policies and intervention plans that are appropriate and in accordance with the conditions of the community. Thus, from surveillance activities will be found the prevalence and risk factors for stunting in infants.

\section{METHODS}

This study was a cross-sectional descriptive survey using a structured questionnaire and measurements of height to determine the nutritional status of children under five years old and to examine the impact of socioeconomic, demographic and child feeding practice on nutritional status of children. The study was carried out in the working area of Sukowono Public Health Center. The respondents were taken by multi-stage stratified cluster random sampling method, 20 posyandu were chosen from 8 villages. Simple random sampling was used to select 249 children children under five years from posyandu. Research data collection was conducted from May to June 2019. Anthropometric Measurements include all information including the child's age, gender and other data, was obtained by interviewing the caregivers. The nutritional status of children less than 5 years old was measured anthropometrically. Measurement of recumbent length (height with child over 2 years) were taken to the nearest of $0.1 \mathrm{~cm}$ (World Health Organization, 1995). The heightfor-age measurement status was calculated showed in standard deviation (SD) units (Z-score) from the median of the reference population. Children with a measurement of $<-2 \mathrm{SD}$ units below the median of the reference population were considered short for their age (stunted) and children with 
measurement of $<-3$ SD units below the median were considered to be severely stunted. Sociodemographic and child development variables were adopted from conceptual framework of Jiang, et.al (2014). In this model variables were divided into three groups: distal factors were indicated by the socioeconomic variables (caregiver's education, occupation, marital status, income, number of people in household). Intermediate factors included maternal variables (pregnancy anaemia, nutrition improved during pregnancy, premature birth, mode of delivery, initiation of breastfeeding, mother's age at delivery) and proximal factors which include birthweight, diarrhea in previous 2 weeks, coughing in previous 2 weeks, duration of exclusive breastfeeding (classified as exclusive breastfeeding for 6 months or not), time of weaning, children's food cooked alone and whether children were given calcium supplements. The SPSS version 23.0 program was used to analyse the data and statistical significance was set at $P<0.05$. Hierarchical logistic regression was used to analyse the effects of socioeconomic, demographic and child feeding practice on nutritional status of children.

\section{Ethical approval}

Ethics committee of Faculty of Health Science University of Muhammadiyah Jember approved the study. The aim and objectives of the study, as well as a detailed explanation of the procedures to be employed, were explained to the caregiver of the selected child both verbally and in the form of an information sheet. Informed oral consent was obtained from the child's caregiver prior to the measurements.

\section{RESULT AND DISCUSSION}

A total of 249 children were included in the sample. Demographic details are shown in Table 1.

Table 1. Demographic variables of the study participants by descriptive statistic

\begin{tabular}{lrr}
\hline Variabel & $\mathbf{n}$ & \% \\
\hline Caregiver's education & & \\
Uncompleted elementary school & 6 & 2.4 \\
Elementary school & 94 & 37.8 \\
Primary school & 67 & 26.9 \\
$\quad$ Middle school & 66 & 26.5 \\
$\quad$ High school or higher & 16 & 6.4 \\
Caregiver's occupation & & \\
$\quad$ Housewifes & 200 & 80.3 \\
Farmers & 16 & 6.4 \\
$\quad$ Entrepreneurs & 18 & 7.2 \\
$\quad$ Private employees & 7 & 2.8 \\
$\quad$ Government employees & 6 & 2.4 \\
$\quad$ Other & 2 & 0.8 \\
Annual household income & & \\
$\quad$ < Rp. 2.100.000 & 207 & 83.1 \\
$\quad$ Rp. 2.100.000 & 42 & 16.9 \\
Caregiver's marital status & & \\
$\quad$ Married & 246 & 98.8 \\
\hline
\end{tabular}




\begin{tabular}{crr}
\hline Divorce & 3 & 1.2 \\
Number of people in household & & \\
1-3 members & 63 & 25.3 \\
$3-6$ members & 165 & 66.3 \\
$>6$ members & 21 & 8.4 \\
\hline
\end{tabular}

Based on table 1 it is known that majority of caregiver's education were elementary school. In terms of work the average mother does not work or become a housewife. Household income is still relatively low (below the minimum wage). Marital status of majority married but there were 3 respondents who were widowed. The number of family members is the majority of extended family because the number of family members averages 3-6 people.

Table 2. Maternal History of Respondents with Statistical Descriptions

\begin{tabular}{lrr}
\hline Variabel & $\mathbf{n}$ & \% \\
\hline Mother's age at pregnancy & & \\
$\quad<20$ & 77 & 30.9 \\
$20-35$ & 164 & 65.9 \\
$\quad>35$ & 8 & 3.2 \\
Pregnancy anaemia & 46 & 18.5 \\
$\quad$ Yes & 203 & 81.5 \\
$\quad$ No & & \\
Premature birth & 31 & 12.4 \\
$\quad$ Yes & 218 & 87.6 \\
$\quad$ No & & \\
Mode of delivery & 214 & 85.9 \\
$\quad$ Spontaneous labour & 31 & 12.4 \\
Vacum & 4 & 1.6 \\
Sectio Caesarea & & \\
Initiation of breastfeeding & 153 & 61.4 \\
$\quad$ Within 0.5 hours & 48 & 19.3 \\
$\quad$ 0.5 - 1 hours & 48 & 19.3 \\
$\quad>1$ hours & & \\
\hline
\end{tabular}

Table 2 shows that the majority mother's age at pregnancy 20 - 35 years, but the percentage of mothers at risk of pregnancy is still high ( $<20$ years and $>35$ years). Judging from the history of maternal health, it turns out there are still mothers who have anemia and a history of premature birth. Type of labor the majority of spontaneous and as soon as possible initiation of early breastfeeding.

The research results seen from the demographic data of mothers showed that the majority of mothers had low levels of education. The low level of maternal education is one of the risk factors for stunting in infants (Jiang, et.al, 2016). The level of education contributes to the incidence of stunting because the level of education is a good measure of whether or not the mother's knowledge is adequate for her toddler nutrition. Mother's behavior in providing nutrition to toddlers is a factor causing stunting in toddlers (Ministry of Health, 2012). The prevalence of short children living in households with uneducated household heads is 1.7 times higher than the prevalence among children living in households with highly educated household heads (Ministry of Health, 2018). 
The demographic data of mothers is seen from the types of work of the majority of housewives. But it turns out that mothers who do not work is not a guarantee that more free time to care for children compared to working mothers will ensure that their toddler nutrition will be fulfilled. In fact, although the majority of mothers do not work, there are still many stunted toddlers. These results differ from studies which state that working mothers are more at risk of having stunting toddlers because of the lack of time to care for children (Chunling, et.al, 2016). Parenting is indeed the main key to the fulfillment of a toddler's nutrition. Mothers who are not working should make use of free time to provide the best parenting for their toddlers. However, due to the low level of maternal education, this becomes very contradictory despite the free time, so that inadequate knowledge of mothers regarding the fulfillment of toddler nutrition also contributes to stunting.

In terms of family income the majority is still below the Regional Minimum Wage (UMR). This is very related to the fulfillment of family nutrition. The lower the household income, the more risk is the fulfillment of underfive nutrition. Toddlers must get a variety of foods to introduce flavor and obtain nutrients from the food consumed (Ministry of Health, 2012). One factor that contributes to the occurrence of stunting is the family's financial condition (Chunling, et.al, 2016). To obtain family food needs, of course, sufficient financial conditions are needed so that toddler food in accordance with the guidelines for balanced nutrition. Adequate nutrition for infants will minimize the risk of stunting. This family's financial condition is also related to the number of family members. The majority of family members are large families so this also has an impact on the amount of living expenses to be incurred by the family.

The impact of this family demographic condition causes the high prevalence of stunting in children under five, even there is still a condition of nutritional status of children under five that is very short. The prevalence of short children is very high, affecting one in three children under five, which is a proportion that is a public health problem according to WHO criteria (UNICEF, 2012).

Not much different from the results of the study that the proportion of short children in the poorest population quintile is almost double the proportion of children in the highest wealth quintile. Rural areas have a greater proportion of short children (40\%) compared to urban areas (33\%) (Ministry of Health, 2012).

Table 3. Individual Variable with Statistical Descriptions

\begin{tabular}{lrr}
\hline Variabel & $\mathbf{n}$ & $\%$ \\
\hline Child's gender & & \\
$\quad$ Boy & 128 & 51.4 \\
$\quad$ Girl & 121 & 48.6 \\
Low birthweight & 5 & 2.01 \\
$\quad$ Yes & 244 & 97.9 \\
$\quad$ No & & \\
Diarrhoea in previous 2 weeks & 41 & 16.5 \\
$\quad$ Yes & 208 & 83.5 \\
$\quad$ No & & \\
Coughing in previous 2 weeks & 85 & 34.1 \\
$\quad$ Yes & 164 & 65.9 \\
$\quad$ No & & \\
Duration of exclusive breastfeeding &
\end{tabular}




\begin{tabular}{lrr}
\hline Exclusif breastfeeding ( $\geq 6$ months) & 179 & 71.9 \\
No (<6 months) & 70 & 28.1 \\
Time of weaning & 15 & 6.0 \\
$\quad<4$ months & 33 & 13.3 \\
4 - 6 months & 34 & 13.7 \\
$\quad$ - 8 months & 167 & 67.1 \\
$\quad>8$ months & & \\
Children's food cooked alone & 216 & 86.7 \\
$\quad$ Yes & 33 & 13.3 \\
$\quad$ No & & \\
Whether children were given cod liver oil & 115 & 46.2 \\
Yes & 134 & 53.8 \\
$\quad$ No & & \\
Whether children were given calcium & & \\
supplementary & 84 & 33.7 \\
$\quad$ Yes & 165 & 66.3 \\
$\quad$ No & & \\
\hline
\end{tabular}

Based on table 3 it is known that the child's gender of male babies is not much different in number from female babies. Judging from the baby's medical history, there are still babies who have a history of diarrhea and cough in the last 2 weeks. For exclusive breastfeeding, it turns out there are still babies who are not given exclusive breastfeeding. The average weaning time for babies is over 8 months. Most babies who have been given MP-ASI are self-cooking, but apparently there are still many mothers who do not provide extra fat and calcium for baby's growth and development even though these components are important to give to babies.

Table 4. Risk Factors for Stunting with Regression Logistic Analysis

\begin{tabular}{|c|c|c|}
\hline Variabel & $P$ value & OR $(95 \% \mathrm{Cl})$ \\
\hline Pregnancy Anaemia & 0.047 & $4.656(1.018 ; 21.296)$ \\
\hline $\begin{array}{l}\text { Duration of exclusive breastfeeding } \\
\text { (<6 months) }\end{array}$ & 0.05 & $3.190(0.983 ; 10.355)$ \\
\hline Low birthweight & 0.035 & $4.090(1.063 ; 3.601)$ \\
\hline
\end{tabular}

Based on table 4 it is known that mothers who have a history of anaemia during pregnancy have a 4.6 chance of having a stunting baby compared to mothers who have no history of anemia during pregnancy after being controlled by a variable duration of exclusive breastfeeding and low birthweight $(95 \% \mathrm{Cl}$ OR: 1,$018 ; 21,296)$. Duration of exclusive breastfeeding ( $<6$ months) have a 3.1 chance of suffering from stunting compared to exclusive breastfeeding (>6 months) after being controlled by a variable pregnancy anemia and low birthweight (95\% Cl OR: $0.983 ; 10.355)$. Low birthweight have 4.0 chance experiencing stunting compared to non low birthweight after being controlled by a variable pregnancy anemia and duration of exclusive breastfeeding $(95 \% \mathrm{Cl}$ OR: 1.063;3.601).

Based on logistic regression it is known that the risk factor for stunting in terms of maternal history is maternal anemia during pregnancy. This is related to the fulfillment of maternal nutrition during pregnancy. In line with the results of the 2013 Riskesdas mention the condition of food consumption of pregnant women and toddlers in 2016-2017 shows in Indonesia 1 in 5 pregnant women are malnourished, 7 out of 10 pregnant women are lacking calories and protein (Ministry of 
Health, 2012). Prolonged malnutrition that occurs from the fetus in the womb until the beginning of the child's life (First 1000 Days of Birth). The reason is due to low access to nutritious food, low intake of vitamins and minerals, and poor diversity of food and animal protein sources.

Maternal factors and poor parenting, especially in the behavior and practice of feeding children, are also the cause of child stunting if the mother does not provide adequate and good nutrition. Mothers whose adolescents lack nutrition, even during pregnancy, and lactation will greatly affect the growth of the child's body and brain.

Low levels of hemoglobin in the blood for a long time will result in low nutritional intake by the mother during pregnancy. Anemia occurs when the body lacks red blood cells that function to spread oxygen throughout the body. Mothers who have a history of anemia are more at risk of having a stunting baby than healthy mothers. This is related to other risk factors, namely mothers who have a history of anemia during pregnancy will be at risk of giving birth to babies with low birth weight, so this condition is also closely related to long-term stunting as a side effect due to chronic malnutrition. in toddlers.

The WHO (WHO/UNICEF 2006) suggests that breast milk should be the only food for the first 6 months after birth. The present study supports this recommendation of WHO that the exclusive breastfeeding less than 6 months is a protective factors for children. Low birthweight was a significant risk factor for stunting, again similar to other studies (Ricci \& Becker 1996; Nojomi et al. 2004).

\section{CONCLUSION AND RECOMMENDATION}

Mothers who have a history of anaemia during pregnancy have a 4.6 chance of having a stunting baby compared to mothers who have no history of anemia during pregnancy after being controlled by a variable duration of exclusive breastfeeding and low birthweight (95\% Cl OR: 1,018; 21,296 ). Duration of exclusive breastfeeding ( $<6$ months) have a 3.1 chance of suffering from stunting compared to exclusive breastfeeding ( $>6$ months) after being controlled by a variable pregnancy anemia and low birthweight (95\% Cl OR: 0.983;10.355). Low birthweight have 4.0 chance experiencing stunting compared to non low birthweight after being controlled by a variable pregnancy anemia and duration of exclusive breastfeeding (95\% Cl OR: 1.063;3.601).

The results of this study indicate that malnutrition is still a major public health problem among children under 5 years of age in Jember. These results highlight the need for early intervention programmes aimed at reducing malnutrition in children.

\section{REFERENCES}

Casale, D, Desmond, C \& Richter, L. (2014). The association between stunting and psychosocial development among preschool children: a study using the South African Birth to Twenty cohort data. Child: care, health and development. doi:10.1111/cch.12143 
Chunling Lu, Iv'an Mej'ıa-Guevara, Kenneth Hill, Paul Farmer, S. V. Subramanian, \& Agnes Binagwaho. (2016). Community-based health financing and child stunting in Rural Rwanda. Public Helath Policy. Vol 106, No. 1

Jahari, A.B. \& Persatuan Ahli Gizi Indonesia (PERSAGI). (2018). Penurunan masalah balita stunitng. Disajikan pada Rapat Kerja Kesehatan Nasional 2018

Hoddinott, J., Maluccio, J. A., Behrman, J. R., Flores, R. \& Martorell, R. (2008) Effect of a nutrition intervention during early childhood on economic productivity in Guatemalan adults. Lancet, $371,411-416$.

Ministry of Health Indonesia. (2012). Direktorat Jenderal Bina Gizi dan Kesehatan Ibu dan Anak. Petunjuk pelaksanaan surveilans gizi. Jakarta: Kementerian Kesehatan Republik Indonesia

Ministry of Health Indonesia. Badan Penelitian dan Pengembangan Kesehatan. Hasil utama RISKESDAS 2018. Jakarta: Kementerian Kesehatan

Polit, D.F., \& Beck C.T., (2012). Nursing research: Generating and assesing evidence for nursing practice. 9 th ed. Wolter Kluwer Health: Lippincott Williams \& Wilkins.

Sobrino, M, Gutiérrez, C, Alarcón, J, Dávila, M \& Cunha, A. J. (2016). Birth interval and stunting in children under five years of age in Peru (1996-2014). Child: care, health and development. doi:10.1111/cch.12420

Stein, A. D., Wang, M., Martorell, R., Norris, S. A., Adair, L. S., Bas, I., Sachdev, H. S., Bhargava, S. K., Fall, C. H., Gigante, D. P., Victora, C. G. \& Cohorts Group (2010) Growth patterns in early childhood and final attained stature: data from five birth cohorts from lowand middleincome countries. American Journal of Human Biology, 22, 353-359.

Tim Nasional Percepatan Penanggulangan Kemiskinan (TNP2K), Kementerian Koordinator Bidang Pembangunan Manusia dan Kebudayaan, \& Kementerian PPN/ Bappenas. (2017). Pemilihan10 Desa Prioritas di 100 Kabupaten/Kota Prioritas Penanganan Kemiskinan dan Stunting

UNICEF Indonesia. (2012). Ringkasan Kajian. Jakarta: UNICEF Indonesia

WHO (2015) Report of a WHO technical consultation on birth spacing. Geneva, Switzerland June 2015.

WHO (2014) Child growth standards. Special SPSS macros. Available at: http://www.who.int/childgrowth/software/macros special_spss/en/index.htm/\#

Y. Jiang, X. Su, C. Wang, L. Zhang, X. Zhang, L. Wang and Y. Cui. Prevalence and risk factors for stunting and severe stunting among children under three years old in mid-western rural areas of China. Child: care, health and development. doi:10.1111/cch.12148 